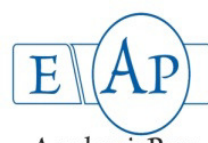

AcademicPres

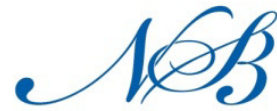

Notulae Scientia Biologicae

\title{
Potential of Microsatellites Markers for the Genetic Analysis of Bryophytes
}

\author{
Saumy PANDEY, Vinay SHARMA, Afroz ALAM* \\ Banasthali University, Departament of Bioscience and Biotechnology, Banasthali304022, Rajasthan India; saumbhavi@gmail.com; \\ vinaysharma30@yahoo.co.uk; afrozalamsafui@gmail.com ("correspondingauthor)
}

\begin{abstract}
Microsatellites have increasingly being used to study genetic diversity, phylogeny, population genetics, population ecology and genetic mapping of bryophytes. Due to co-dominant and highly reproducible features, microsatellites became markers of choice for several genetic analyses of bryophytes. However, the major limitation is de novo isolation of microsatellites from the interest species which were studied and gave genomic libraries. Initially, traditional methods of microsatellite development were tedious and time consuming, but due to the sequencing of several bryophytes available in public databases, advancement in PCR technologies and computer software, have cumulatively facilitated the development of microsatellites for bryophytes study. This review examines the features, strategies for the development of microsatellites and their utilization in many aspects of genetic and ecological studies of bryophytes.
\end{abstract}

Keywords: DNA polymorphism, genetic diversity, genome sequences, molecular markers, microsatellites, moss

\section{Introduction}

Molecular markers are powerful tools for studying the genetic biodiversity, as these markers show Mendelian inheritance, making it possible to trace the fingerprint of each organism and determine the evolutionary history of the species by phylogenetic analysis, studies of genetic relationship, population genetic structures and genetic mapping. Hamada et al. (1982) first showed the existence of microsatellites in eukaryotic genomes, while Litt and Luty (1989) used the term "microsatellites" during their study on cardiac gene.

Bryophytes significantly contribute to the biodiversity of terrestrial ecosystems. However, the bryodiversity studies based on morphological features are often hindered by the unclear species circumscription, identification difficulties of bryophyte taxa and the influence of the environment in the evolution of those characters. Currently, DNA sequence analyses provide new tools for the study of diversity within and among species (Chakravarthi and Naravaneni, 2006; Jonah et al., 2011). Several studies have revealed the difference in information provided by the morphological and molecular data, supporting the relevance of molecular markers (Zouhair et al., 2000; Sotiaux et al., 2009; Shaw, 2009; Vanderpoorten and Shaw, 2010). Thus, it might be said that molecular data provide a more accurate representation of phylogenetic history and relationships than morphological characters alone (Holyoak and Pedersen, 2007).

Because of the presence of both highly conserved and variable regions, Restriction Fragment Length Polymorphism (RFLP) (Boisselier-Dubayle et al., 1995a; Patterson et al., 1998), Random Amplified Polymorphic DNA (RAPD) (Boisselier-Dubayle et al., 1995a, 1995b; Skotnicki et al., 1998a; Wolfe and Liston, 1998; Korpelainen and Allen, 1999) and microsatellites or Simple Sequence Repeats (SSRs) (Becker and Heun, 1994) have been used to reveal the genetic relationship among different taxa of bryophytes. Of all these techniques that facilitate the evaluation of genetic diversity, microsatellites or SSR are preferred, since it would make possible to detect in a simple manner, a large number of DNA polymorphism (Park et al., 2009).

\section{Microsatellites characteristics}

Microsatellites (Litt and Luty, 1989) also known as Simple Sequence Repeats (SSRs) (Tautz et al., 1986; Jacob et al., 1991), Short Tandem Repeats (STRs) (Edwards et al., 1991) or Simple Sequence Length Polymorphism (SSLPs) (McDonald and Potts, 1997), are tandem repeats of 1-6 nucleotides (Gupta et al., 1996; Thiel et al., 2003) that mutate frequently as compared to other genomic regions and hence show high levels of genetic variation (Farooq and Azam, 2002). The variation of the tandemly repeated units is mainly due to strand slippage during DNA replication (Levinson and Gutman, 1987), where the repeats allow a new matching via excision or addition of repeats (Schlotterer and Tautz, 1992). As the probability of strand slippage during replication is greater than point mutations, the microsatellite loci tends to be hyper-variable. Microsatellite assays demonstrate extensive inter-individual length polymorphisms, within the employment of specific primer sets during PCR analysis, thus with unique loci using discriminatory primer sets.

Microsatellites can be classified on the basis of repeated sequences as (a) perfect repeats: they have only perfect repetitions of nucleotide sequences, e.g. (GC) ${ }_{10}$; (b) imperfect repeats: have repeated sequences that are interrupted by different nucleotides that are not repeated, e.g. $(\mathrm{GC})_{10} \mathrm{AT}(\mathrm{GC})_{10} ;(\mathrm{c})$ composite 
38

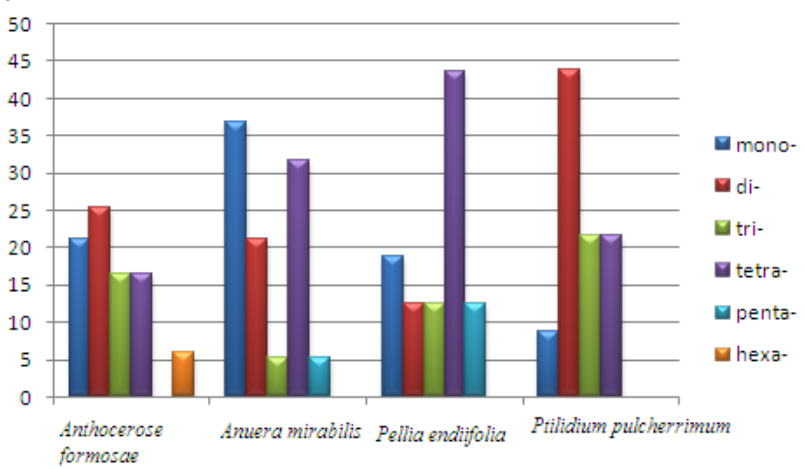

Fig. 1. The frequency of each SSR repeats (mono- to hexa) in four bryophytes species (Shanker 2013a, 2013b, 2014a, 2014b)

repeats: have two or more different motifs in tandem, e.g. $(\mathrm{GC})_{7}(\mathrm{AT})_{6}$. The composite repeats can be perfect or imperfect. Mononucleotide repeats face problems during PCR amplification, whereas di-, tri- and tetranucleotide repeats sequences are used for the majority of the molecular genetic studies (Selkoe and Toonen, 2006). Dinucleotide repeats account for the majority of microsatellites for several species $(\mathrm{Li}$ et al., 2002). A trinucleotide and hexanucleotide repeat usually occurs in the coding regions as they do not cause a frame-shift (Toth et al., 2000). Microsatellites with longer repeats are less common and data regarding their evolution is limited ( $\mathrm{Li}$ et al., 2002). The level of inter- and intraspecific polymorphism is higher when the tandem repeats are greater (Queller et al., 1993). The abundance of one particular repeat unit of a nucleotide in SSR motifs of a chloroplast genome sequence of four different genera of bryophytes is shown in Fig. 1 .

Microsatellites can also be present in organelle genomes such as those of mitochondria and chloroplast. The chloroplast and mitochondrial genomes usually have an uniparental mode of transmission, so they display different patterns of genetic differentiation compared to nuclear alleles (Provan et al., 1999a, 1999b). Thus, for a complete understanding of plant genetic variation and evolution, all three genomes (nuclear, chloroplast and mitochondria) must be considered; therefore, in addition to nuclear microsatellites, marker techniques based on the chloroplast and mitochondrial microsatellites have also been developed (Agrawal et al., 2008). The complete genome sequence of mitochondrial and chloroplast genome is available for several species of bryophytes (Table 1), thus several microsatellites markers have been developed for bryophytes (Zhao et al., 2014; Shanker, 2013a, 2013b, Shanker 2014) and utilized for studding their genetic diversity, population ecology, phylogeny and evolution study.

\section{Useful characteristics of microsatellites in the study of bryophytes:}

1. Co-dominance: The co-dominant genetics of microsatellites offer a major advantage over other fingerprinting approaches such as RAPDs, AFLPs and ISSRs, especially for studies of hybridization and mating patterns, since both parental genomes can be detected directly by PCR amplification.

2. High abundance: Microsatellites are present in both coding and non-coding regions (Tautz and Renz, 1984; Gupta et al., 1994; Toth et al., 2000) with higher density in the noncoding regions of eukaryotes (Hancock, 1995; Li et al., 2002).
Microsatellites are found to be dispersed in diverse genomic regions, including 3'-UTRs, 5'-UTRs, exons and introns (Rajendrakumar et al., 2007). In plants, SSRs are much more abundant and preferentially associated within untranslated regions (UTRs) of the transcribed regions (Morgante et al., 2002).

3. High allelic diversity: Microsatellite markers have high rates of mutation (on average $5 \times 10^{-4}$ mutation per locus per generation) thus resulting in high levels of allelic diversity.

4. High reproducibility: Microsatellites are highly reproducible and produce consistent data when used by different research laboratories (Saghai-Maroof et al., 1984). Also, lengthy primers and high annealing temperatures enhance the reproducibility during genotyping.

5. Transferability: Microsatellites are transferable, because their flanking regions are highly conserved across taxa, allowing cross-species amplification. The transferability of SSRs derived from EST databases (EST-SSR) is greater than that of SSRs derived from enriched genomic DNA libraries. The EST-SSRs originate from expressed regions, and therefore they are more conserved across a number of related species than non-coding regions (Varshney et al., 2005).

6. Microsatellites require a low quantity of template DNA: As SSR is PCR based techniques, the quantity of DNA required for SSR-PCR fingerprinting is very low (Kumar et al., 2009; Wolko et al., 2010).

\section{Development of microsatellites}

In spite of the wide applicability of microsatellite markers in bryodiversity studies, the number of microsatellite marker developed for bryophytes is very deficient (Provan and Wilson, 2007; Hutsemékers et al., 2008; Liu et al., 2010; Sawicki et al., 2012). Because the designing of primers, sequence information is required, thus the microsatellites have to be isolated de novo from the species studied for the first time. As the frequency of microsatellites in plants' genome is relatively less compared to animals' genome, it causes problems with their large scale isolation (Powell et al., 1996). Traditionally, microsatellite loci were isolated from partial genomic libraries of the species of interest by screening several thousands of clones through colony hybridization. This method is simple, but inefficient for species with low microsatellite frequencies (Zane et al., 2002). Conventional genomic library construction and subsequent screening are time consuming, tedious, costly and require high level of expertise. Even more, AT dinucleotides, which are the most abundant type of SSR in plants, are difficult to isolate from libraries because they are palindromic (Powell et al., 1996). Therefore, several alternative methods have been developed in order to reduce the time invested in microsatellite isolation and to significantly increase the yield of microsatellite loci. These methods involve database mining, transferability of markers and sequencing.

\section{Development of microsatellite through genomic library construction}

For microsatellite loci isolation from genomic libraries of interest species several methods have been developed which include selective hybridization (Karagyozov et al., 1993; Armour et al., 1994; Kandpal et al., 1994; Hamilton et al., 1999), primer extension enrichment (Ostrander et al., 1992; Paetkau, 1999) and several other methods which have been 


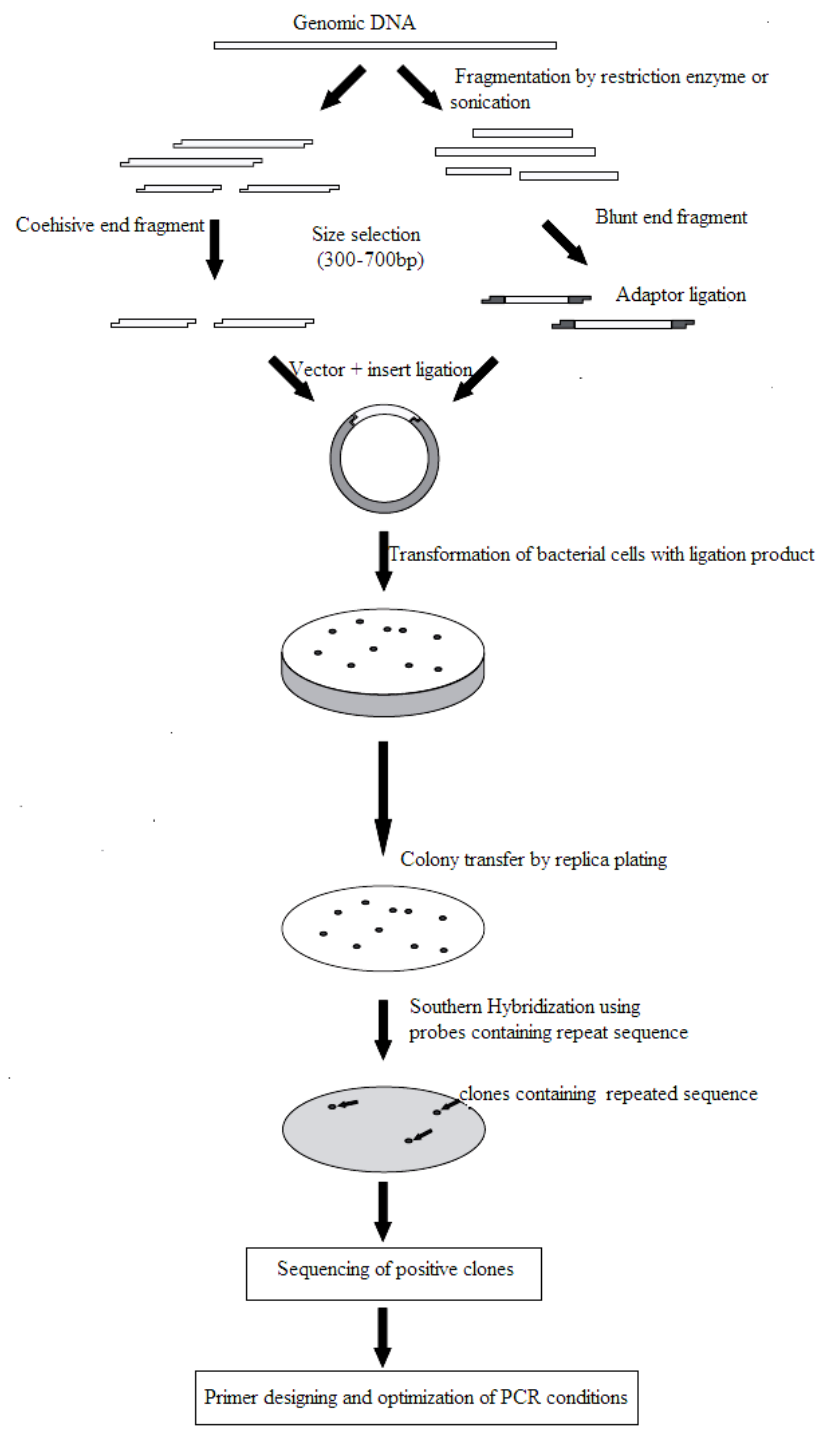

Fig. 2. Protocol for the development of SSR markers through SSRenrichment method (modified scheme from Zane et al., 2002)

reviewed extensively (Zane et al., 2002; Weising et al., 2005; Kalia et al., 2011). Hutsemékers et al. (2008) identified 8 nuclear microsatellite loci in the aquatic moss Platyhypnidium riparioides using the microsatellite-enriched library's method. The markers amplified 3-7 alleles per locus and can further be used to investigate the diversity and population genetic structure.

Microsatellite isolation through genomic library construction is very tedious and time consuming and, it is not recommended for the taxa containing a low frequency of microsatellites, such as plants, or when a large number of microsatellites are required, as in the case of studies on genetic distances among populations (Zhivotovsky and Feldman, 1995; Cooper et al., 1999) or when constructing a genetic map (Liu, 1997).

A general protocol for the development of SSR markers through SSR-enrichment method is described in Fig. 2 (modified scheme from Zane et al., 2002).

Microsatellite markers can be developed by cloning PCR products generated from RAPD primers, ISSR primers, AFLP

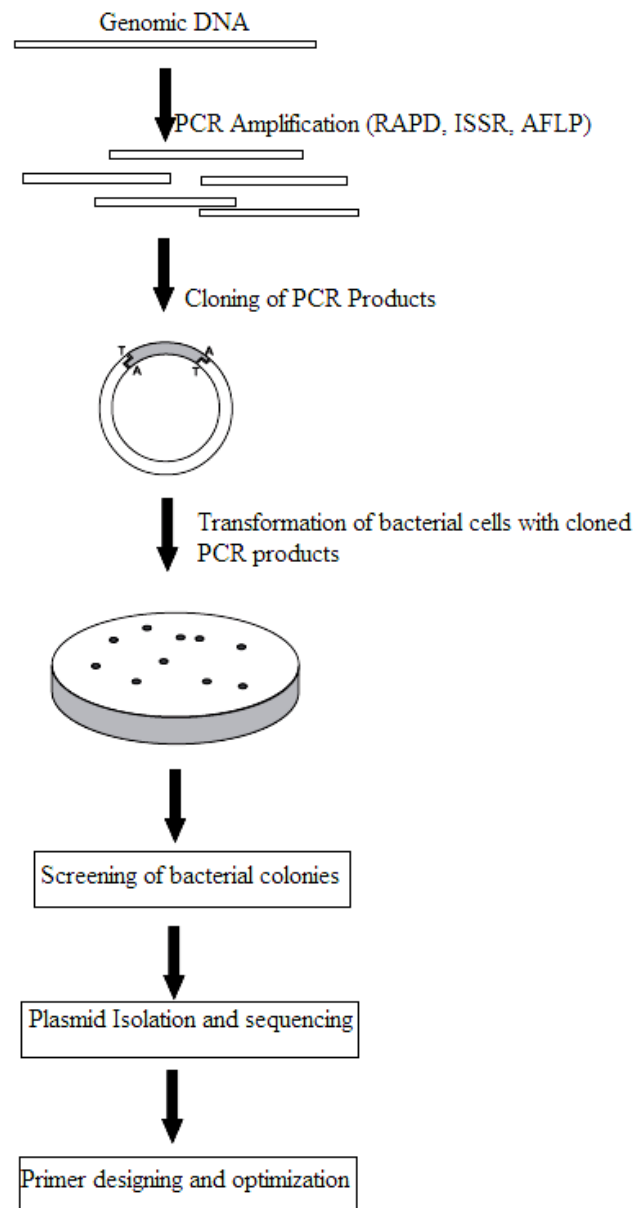

Fig. 3. Protocol for the development of SSR markers through cloned PCR products (modified scheme from Zane et al., 2002)

or 5' anchored microsatellite primers. Liu et al. (2010) used FIASCO (FAST isolation of AFLP sequence containing repeats) protocol (Zane et al., 2002) to develop 13 microsatellite primers for Ptychomitrium gardneri. Out of which 8 primer pairs produced polymorphic products. These markers amplified three to four alleles per locus. Cross amplification of these primers was tested on four Polytrichum species (P. linearifolium, $P$. wilsonii, $P$. fauriei and $P$. sinense) whereas 5 primer pairs amplified in $P$. linearifolium and $P$. wilsonii. ISSR cloning method was used by Provan and Wilson (2007) to develop 9 microsatellites for the moss species Sphagnum capillifolium, which amplified 3-7 alleles per locus and also exhibited cross species amplification. A general protocol for the development of SSR markers through cloned PCR products is described in Fig. 3 (modified scheme from Zane et al., 2002).

\section{Database mining}

Currently, microsatellite markers are developed by screening the already submitted sequence information of ESTs, cDNA and fully sequenced genes in a public database such as EMBL, GenBank, or DNA Data Bank of Japan (DDBJ), for the presence of microsatellite in the nuclear genome or within the organelle genome. Initially, unspecific alignment tools such as BLASTN (Altschul et al., 1990) were used for database searches. Now days, a number of web based SSR search 
Table 1. The complete genome sequence of mitochondrial and chloroplast genomes of bryophytes submitted at NCBI

\begin{tabular}{|c|c|c|c|c|}
\hline S.No. & Organellar genome & Species & Genome size (bp) & Reference \\
\hline & \multirow{10}{*}{ Chloroplast genome } & Liverworts & & \\
\hline 1 & & Aneura mirabilis & 108007 & Wickett et al., 2008 \\
\hline 2 & & Marchantia polymorpha & 121024 & Ohyama et al., 1986 \\
\hline 3 & & Ptilidium pulcherrimum & 119007 & Forrest et al., 2011 \\
\hline & & Mosses & & \\
\hline 4 & & Physcomitrella patens & 122890 & Sugiura et al., 2003 \\
\hline \multirow[t]{2}{*}{5} & & Tortula ruralis & 122630 & Oliver et al., 2010 \\
\hline & & Hornworts & & \\
\hline \multirow[t]{2}{*}{6} & & Anthoceros formosae & 161162 & Kugita et al., 2003 \\
\hline & & Liverworts & & \\
\hline 7 & \multirow{9}{*}{ Mitochondrial genome } & Marchantia polymorpha & 186608 & Oda et al., 1992 \\
\hline 8 & & Pleurozia purpurea & 168526 & Wang et al., 2009b \\
\hline 9 & & Treubia lacunosa & 151983 & Liu et al., 2011 \\
\hline & & Mosses & & \\
\hline 10 & & Physcomitrella patens & 105340 & Terasawa et al., 2007 \\
\hline \multirow[t]{2}{*}{11} & & Anomodon rugelii & 104239 & Liu et al., 2011 \\
\hline & & Hornworts & & \\
\hline 12 & & Phaeoceros laevis & 209482 & Xue et al., 2010 \\
\hline 13 & & Megaceros aenigmaticus & 184908 & Li et al., 2009 \\
\hline
\end{tabular}

Table 2. Total number of microsatellite loci identified by screening mitochondrial genome sequence of bryophytes (Zhao et al., 2014)

\begin{tabular}{|c|c|c|}
\hline S. No. & Species & Total no. of microsatellite loc \\
\hline & Liverwort & \\
\hline 1 & Marchantia polymorpha & 88 \\
\hline \multirow[t]{2}{*}{2} & Pleurozia purpurea & 69 \\
\hline & Mosses & \\
\hline 3 & Physcomitrella patens & 83 \\
\hline \multirow[t]{2}{*}{4} & Anomodon rugelii & 59 \\
\hline & Hornworts & \\
\hline 5 & Phaeoceros laevis & 55 \\
\hline 6 & Nothoceros aenigmaticus & 69 \\
\hline
\end{tabular}

Table 3. Total number of microsatellites identified by screening chloroplast genome sequence of bryophytes (Shanker et al., 2013a, 2013b, 2014a, 2014b)

\begin{tabular}{lll}
\hline S.No. & Species & Total no. of microsatellites \\
\hline 1 & Anthoceros formosae & 67 \\
2 & Aneura mirabilis & 19 \\
3 & Pellia endiviifolia & 16 \\
4 & Ptilidium pulcherrimum & 23 \\
\hline
\end{tabular}

software such as MISA, SSR locator, CUGssr, Sputnik and SSRSEARCH are used for screening and hence for the development of SSR markers for different species. The microsatellite markers derived from EST sequence are more useful when compared to markers derived from anonymous regions (Varshney et al., 2005; Kashi and King, 2006; Varshney et al., 2006). EST-SSRs were derived from several species of bryophytes such as Marchantia polymorpha, Synchtria ruralis and Physcomitrella patens (Victoria et al., 2011). Shanker (2014b) designed 22 SSR primers from 23 CpSSR, by screening the chloroplast genome sequence of Ptilidium pulcherrimum.

The full genome sequences of chloroplast and mitochondrial genomes (Table 1) are available for many species of bryophytes, thus several microsatellite markers have been developed for bryophytes screening.

Using database search method, Zhao et al. (2014) and Shanker (2013a, b) screened the mitochondrial and chloroplast genome sequences of some bryophytes species submitted in NCBI for the presence of microsatellites loci using MISA software. The number of microsatellites identified is shown in Tables 2 and 3 respectively. Further, these microsatellites regions identified by database mining can be used for designing primers for specific plant groups, which can also be used in the genetic diversity study of related species, due to the transferability of SSR primers.

\section{Next generation sequencing}

The chloroplast genome sequence of leafy liverwort, Ptilidium pulcherrimum, was sequenced using next generation sequencing (Forrest et al., 2011). P. pulcherrimum was the first bryophyte plant to be sequenced using this technology. Sawicki et al. (2012) used next generation sequencing technology to develop 46 microsatellite primer pairs for Orthotrichum speciosum. Out of 92 SSR motifs identified in 89 countings, only 46 had flanking regions suitable for primer design. These 46 primer pairs were tested on 40 individuals of Orthotrichum speciosum collected from 2 populations, revealing 35 polymorphic loci. The designed primer showed transferability of phylogenetically closely related species $O$. affine and $O$. striatum, and distantly related, $O$. diaphanum and $O$. pallens.

\section{Microsatellites points of issue}

In spite of their recognised advantages that microsatellites offer within the genetic analysis, there are few limitations or drawbacks associated with this technique that might affect data analysis (Bonin et al., 2004). Many limitations of microsatellites marker can be avoided by a careful selection of microsatellite loci during the isolation process (Selkoe and Toonen, 2006).

Homoplasy: referring to alleles similar in size, but with different lineages (Jarne and Lagoda, 1996). Due to the homoplasy, the actual allelic diversity between populations is underestimated (Estoup et al., 1995; Jarne et al., 1998; Curtu et al., 2004). Homoplasy is usually common in compound or interrupted repeats (Adams $e t$ al., 2004) and it can be categorized in two groups (a) 
detectable homoplasy, (b) non detectable homoplasy. The detectable homoplasy can be revealed by nucleotide sequencing. The detectable homoplasy only accounts for only $1-2 \%$ for the underestimation of allelic diversity (Adams et al., 2004; Curtu et al., 2004).

In general, homoplasy is less problematic in population genetic analysis, since the chance of homoplasy is proportional to the genetic distance of two individuals or populations (Estoup et al., 2002). However, it creates problems during studies involving highly divergent groups, such as for phylogenetic reconstruction (Estoup et al., 1995).

Null alleles: Sometimes the absence of PCR products is not due to the failure of PCR reaction, but due to the presence of null alleles at the SSR locus. Null alleles arise due to the mutation at primer annealing site and thus prevents the locus amplification (Paetkau and Strobeck, 1995). Dakin and Avis (2004) study showed that a low rate of null alleles may have a negligible effect on most population analysis, but have considerable impact on the parentage analysis. Thus, for consistent amplification it is advised that primer selection should be done carefully before large scale sample analysis.

Shutter bands: Strand slippage during PCR amplification produce shutter bands (Hauge et al., 1993; Ellegren, 2004) that vary in size from the main product by multiples of the length of repeat units (Hauge et al., 1993; Murray et al., 1993; Smulders et al., 1997). Since the Taq polymerase slippage is directly proportional to the number of repeat units and inversely proportional to the length of the repeat unit, the occurrence of shutter bands will be prominent in SSRs with long stretches of a short repeat unit (1-2bp) (Shinde et al., 2003).

\section{Microsatellites applications}

Microsatellites emerge the opportunity to study genetic diversity, population genetics, reconstructing the phylogenetic relationship among and within species, population ecology, biogeography, paternity and ploidy of plants (Arroyo-Garcia et al., 2002; Rajendrakumar et al., 2007; Magain et al., 2010).

\section{Genetic diversity and taxonomy}

Genetic diversity is defined as the variation in nucleotides, genes, chromosomes or whole genomes of organisms (Wang et al., 2009a). Microsatellite analysis of several species of bryophytes exhibit high level of genetic diversity (Wilson and Provan, 2003; Shaw et al., 2008; Hutsemekers et al., 2010), while before these methods it was assumed that bryophytes, having haploid gametophytes, retain a low level of genetic variation due to natural selection. The high level of genetic diversity in bryophytes may be due to multiple-niche selections (Wyatt et al., 1989), inter-locus interaction, e.g. epistasis (Shaw and Beer 1999), sexual reproduction (Wyatt et al., 2005) and somatic mutations (Skotnicki et al., 2005). Paasch et al. (2015) demonstrated that the high level of genetic diversity in the xeric populations of Syntrichia caninervis is mainly due to migration and somatic mutation.
Kophimai et al. (2014) studied genetic diversity in two closely related moss species Scorpidium cossonii and Scorpidium revolvens respectively, using nine microsatellite markers and concluded that Scorpidium cossonii is genetically more diverse than Scorpidium revolvens due to different mating systems, distinct population sizes and different population histories.

Molecular analysis of species provides more accurate information about phylogeny and relationships than molecular characters based analysis. Thus, molecular phylogenetics has gained importance in testing traditional taxonomic hypotheses, especially in taxa with reduced morphologies like bryophytes. In bryophytes, the main reasons for the difficulties in morphological and molecular based analysis of species are the limited characters defining them, the focus on a few key-characters and morphological plasticity due to environment (Vanderpoorten and Goffinet, 2006). Several deviation patterns between morpho-species concepts and molecular phylogenies have been reported (Heinrichs et al., 2009a). Generally, the sequence related markers have been used for molecular phylogenetic studies (Samigullin et al., 1998; Olsson et al., 2009; Bell and Hyvönen, 2010; Merget and Wolf, 2010). Few reports suggest the use of microsatellite markers for the phylogenetic studies. Ramaiya et al. (2010) studied Frullania sp. sampled from North Carolina using nucleotide sequence (trnL, trn F and ITS region); the results revealed no variation and no phylogenetic structure within Eastern North-American species. However, variation at 12 hypervariable microsatellite loci revealed two well defined groups of populations. Also the microsatellite analysis presented these two groups of the population as reproductively isolated biological species.

The genetic structure of the Sphagnum warnstorfii population shows the partial correlation with $\mathrm{pH}$, but independence of the geographic position. Microsatellite markers are also used to study reproductive biology and its effect on genetic variation and genetic structure within populations of several species of bryophytes (Vander-Velde et al., 2000; VanderVelde et al., 2001a; 2001 b; Leonardia et al., 2012). The occurrence of maternal paternity (polyandry) in moss species Sphagnum lescurii (Szovenyi et al., 2009b) was also studied using microsatellite.

\section{Population ecology}

SSR markers are used to investigate the population genetic structure at different spatial scale, the distribution of genetic variation and the level of gene flow within the population. In bryophytes, genetic dispersal occurs mainly through spores, sperms and vegetative fragments. Thus, gene flow can be limited and genetic isolation by distance occurs within populations (Wright, 1943; Vekemans and Hardy, 2004). The nature of gene flow within population not only affects the genetic structure of population, but also the ability of local adaptation of a population which may result in an independent evolution of the populations, thus causing speciation (Slatkin, 1985). In bryophytes, there are only a few studies that test the relation between genetic structure and environmental factors (Szovenyi et al., 2009a; Hutsemekers, 2010; Karlin et al., 2011a; Johnson, 2012; Szovenyi et al., 2012). Mikulaskova et al. (2015) used 12 microsatellite loci analysis to reveal the relation between Sphagnum warnstorfii genetic variability within different populations and $\mathrm{pH} /$ calcium gradient in central Europe. 
42

Habitat fragmentation has adverse effects on the genetic biodiversity because the decrease in the level of gene flows. The habitat fragmentation due to harvesting of peat moss (Polytrichum commune) has been studied using microsatellites (Wilson and Provan, 2003). The authors reported the deleterious effect of habitat fragmentation on the genetic diversity due to the process of genetic drift (Wilson and Provan, 2003; Leonardia, 2012). However, the value of genetic diversity obtained for Polytrichum formosum population using microsatellite was higher than the one obtained using allozymes. Further, the value of genetic diversity $(\mathrm{H})$ calculated within the microsatellite study of Polytrichum commune and Polytrichum formosum populations, was found to be 0.8 and 0.4 respectively. Overall, high genetic diversity suggests more genetic variations in bryophytes, hence somewhat contrasting with the earlier theories of low genetic diversity in bryophyte, based on the haploid dominant life phase (Ennos, 1990; Stenoien and Sastad, 2001).

\section{Biogeography of bryophytes}

Several studies on bryophyte species showed that microsatellite loci can also be used to find the origin and evolution of species and can also help to explain the evolutionary importance of interspecific hybridization and allodiploidization in bryophyte speciation (Sastad et al., 2001; Vander-Velde and Bijlsma, 2004; Sastad, 2005; Ricca and Shaw 2009; Shaw, 2009; Stenoien et al., 2011).

Based on microsatellite variation pattern, Stenoien $e t$ al. (2011) documented that Sphagnum troendelagicum originated before the last glacial maximum, and subsequently immigrated to central Norway by means of spores. Also, the phylogeography of five Polytrichum species within Europe and the presence of asymmetric reproductive isolation between the closely related taxa, Polytrichum commune and Polytrichum uliginosum (Vender-Velde and Biljsma, 2002; Vender-Velde and Biljsma, 2004) was demonstrated using microsatellite markers.

Ricca et al. (2008) showed that microsatellite patterns of heterozygosity are interrelated with genome size, and thus can be used to infer ploidal levels. Karlin et al. (2009), on the basis of microsatellite pattern, concluded that two Southern hemisphere Sphagnum species have triploid gametophytes. Also, Ricca and Shaw (2010) used 12 microsatellite loci and two plastid DNA markers to show allopolyploidy and homoploidy hydridization in the Sphagnum subsecundum complex. Further study using microsatellite markers on Sphagnum subsecundum complex showed the presence of asymmetric interploidal hybridization and the presence of introgression between allodiploid and haploid populations (Ricca et al., 2011). Even more, Karlin et al. (2010) reported that Sphagnum centrale and Sphagnum henryense are allopolyploids. Szovenyi et al. (2008) analyses indicated that both ongoing migration and ancestral polymorphism are important in explaining the intercontinental genetic similarity of peat moss populations, but their relative contribution varies with species. Microsatellites further showed that Sphagnum cuspidatum is one of the parental species of the double allopolyploid Sphagnum falcatulum, a Holantarctic species, reported in Tasmania, New Zealand and Chile. This species was found to occur on every continent except Antarctica (Karlin et al., 2011b).

\section{Conclusions}

The microsatellites have been utilized in several bryological researches, enabling a better understanding of this group of earliest known plants. Microsatellites are emerging as very valuable tools to study the genetic diversity, population genetics, reconstructing phylogenetic relationships among and within species, population ecology, biogeography, paternity and ploidy of bryophytes. Designing of SSR primers requires DNA sequence information, whereas the genome sequences of several bryophytes are available in public databases. Although specific difficulties, SSR markers can be developed to be used for competent studies of closely related species, through cross species amplification. As the genome sequences of more and more species of bryophytes are becoming available through EST or whole genome sequencing, the number of SSR markers is also increasing. Further advancements in microsatellite development protocols, PCR technology and computer software will facilitate the development of molecular markers that are to be used in the several areas of bryological research. Hence, microsatellites have proved to be of immense value in genetic studies of bryophytes and will also lead to novel insights into various studies of bryophytes such as reproductive biology, ecology, phylogeny and taxonomy.

\section{References}

Adams RI, Brown KM, Hamilton MB (2004). The impact of microsatellite electromorph size homoplasy on multilocus population structure estimates in a tropical tree (Corythophora alta) and an anadromous fish (Morone saxatilis). Molecular Ecology 13(9):25792588.

Agrawal M, Shrivastava N, Padh H (2008). Advances in molecular marker technique and their application in plant science. Plant Cell Reports 27(4):617-631.

Altschul SF, Gish W, Miller W, Myers EW, Lipman DJ (1990). Basic local alignment search tool. Journal of Molecular Biology 215(3):403410.

Armour, JA, Neumann R, Gobert S, Jeffreys AJ (1994). Isolation of human simple repeat loci by hybridization selection. Human MolecularGenetics 3(4):599-605.

Arroyo-Garcia R, Lefort F, De-Andres MT, Ibanez J, Borrego J, Jouve N, Cabello F, Martinez-Zapater JM (2002). Chloroplast microsatellite polymorphisms in Vitis species. Genome 45(6):1142-1149.

Becker J, Heun M (1994). Barley microsatellites: allele variation and mapping. Plant Molecular Biology 27(4):835-845.

Bell NE, Hyvonen J (2010). Phylogeny of the moss class Polytrichopsida (Bryophyta): Generic-level structure and incongruent gene trees. Molecular Phylogenetics and Evolution 55(2):381-398.

Boisselier-Dubayle MC, Chaldee M, Guerin L, Lambourdiere J, Bischler H (1995a). Genetic variability in Western European Lunularia (Hepaticae, Lunulariaceae). Fragmenta Floristica Geobotanica 40(1):379-391.

Boisselier-Dubayle MC, Jubier MF, Lejeune B, Bischler H (1995b). Genetic variability in three subspecies of Marchantia polymorpha (Hepaticae): Isoenzymes, RFLP and RAPD markers. Taxon 44(3):363-376. 
Bonin A, Bellemain E, Bronken-Eidesen P, Pompanon F, Brochmann C, Taberlet $P$ (2004). How to track and assess genotyping errors in population genetics studies. Molecular Ecology 13(11):3261-3273.

Chakravarthi BK, Naravaneni R (2006). SSR marker based DNA fingerprinting and diversity study in rice (Oryza sativa $\mathrm{L}$.). African Journal of Biotechnology 5(9):684-688.

Cooper G, Amos W, Bellamy R, Siddiqui MR, Frodsham A, Hill AVS, Rubinsztein DC (1999). An empirical exploration of the (dm)2 genetic distance for 213 human microsatellite markers. American Journal of Human Genetics 65(4):1125-1133.

Curtu AL, Finkeldey R, Gailing O (2004). Comparative sequencing of a microsatellite locus reveals size homoplasy within and between European oak species (Quercus spp.). Plant Molecular Biology Reporter 22(4):339-346.

Dakin EE, Avise JC (2004). Microsatellite null alleles in parentage analysis. Heredity 93:504509.

Edwards A, Civitello A, Hammond HA, Caskey CT (1991). DNA typing and genetic mapping with trimeric and tetrameric tandem repeats. The American Journal of Human Genetics 49(4):746-756.

Ellegren H (2004). Microsatellites: Simple sequences with complex evolution. Nature Reviews Genetics 5:435-445.

Ennos RA (1990). Population genetics of bryophytes. Trends in Ecology and Evolution 5(2):38-39.

Estoup A, Jarne P, Cornuet JM (2002). Homoplasy and mutation model at microsatellite loci and their consequences for population genetics analysis. MolecularEcology 11(9):1591-1604.

Estoup A, Tailliez C, Cornuet JM, Solignac M (1995). Size homoplasy and mutational processes of interrupted microsatellites in two bee species, Apis mellifera and Bombus terrestris (Apidae). Molecular Biology and Evolution 12(7):1074-1084.

Farooq S, Azam F (2002). Molecular markers in plant breeding-II. Some pre-requisites for use. Pakistan Journal of Biological Sciences 5(10):1141-1147.

Forrest LL, Wickett NJ, Cox CJ, Goffinet B (2011). Deep sequencing of Ptilidium (Ptilidiaceae) suggests evolutionary stasis in liverwort plastid genome structure. Plant Ecology and Evolution 144(1):29-43.

Gupta M, Chyi YS, Romero-Severson J, Owen JL (1994). Amplification of DNA markers from evolutionarily diverse genomes using single primers of simple-sequence repeats. Theoretical and Applied Genetics 89(7):998-1006.

Gupta PK, Balyan HS, Sharma PC, Ramesh B (1996). Microsatellites in plants: a new class of molecular markers. Current Science 70(1):45-54.

Hamada H, Petrino MG, Kakunaga T (1982). A novel repeated element with Z-DNA-forming potential is widely found in evolutionarily diverse eukaryotic genomes. Proceedings of the National Academy of Sciences 79(21):6465-6469.

Hamilton MB, Pincus EL, Di-Fiore A, Fleischer RC (1999). Universal linker and ligation procedures for construction of genomic DNA libraries enriched for microsatellites. Biotechniques 27(3):500-507.

Hancock JM (1995). The contribution of slippage-like processes to genome evolution. Journal of Molecular Evolution 41(6):1038-1047.

Hauge XY, Litt MA (1993). Study of the origin of 'shadow bands' seen when typing dinucleotide repeat polymorphisms by the PCR Human Molecular Genetics 2(4):411-415.
Heinrichs J, Hentschel J, Feldberg K, Bombosch A, Schneider H (2009a). Phylogenetic biogeography and taxonomy of disjunctly distributed bryophytes. Journal of Systematics and Evolution 47(5):497-508.

Holyoak DT, Pedersen N (2007). Conflicting molecular and morphological evidence of evolution within the Bryaceae (Bryopsida) and its implications for generic taxonomy. Journal of Bryology 29(2):111-124.

Hutsemeker V, Risterucci AM, Ricca M, Boles S, Hardy OJ, Shaw AJ, Vanderpoorten A (2008). Identification and characterization of nuclear microsatellite loci in the aquatic moss Platyhypnidium riparioides (Brachytheciaceae). Molecular Ecology Resources 8(5):1130-1132.

Hutsemekers V, Hardy OJ, Mardulyn P, Shaw AJ, Vanderpoorten A (2010). Macroecological patterns of genetic structure and diversity in the aquatic moss Platyhypnidium riparioides. New Phytologist 185(3):852-864.

Jacob HJ, Lindpaintner K, Lincoln SE, Kusumi K, Bunker RK, Mao YP, Ganten D, Dzau VJ, Lander ES (1991). Genetic mapping of a gene causing hypertensionin the stroke-prone spontaneously hypertensive rat. Cell 67(1):213-224.

Jarne P, Lagoda PJL (1996). Microsatellites, from molecules to populations and back. Trends in Ecology and Evolution 11(10):424 429.

Jarne P, Daved P, Viard F (1998). Microsatellites, Transposable elements and the X chromosome. Molecular Biology and Evolution 15(1):2834.

Johnson MG, Shaw B, Zhou P, Shaw AJ (2012). Genetic analysis of the peat moss Sphagnum cribrosum (Sphagnaceae) indicates independent origins of an extreme infraspecific morphology shift. Biological Journal of the Linnean Society 106(1):137-153.

Jonah PM, Bello LL, Lucky O, Midau A, Moruppa SM (2011). Review: The importance of molecular markers in plant breeding programmes. Global Journal of Science Frontier Research 11(5):5-12.

Kalia RK, Rai MK, Kalia S, Singh R, Dhawan AK (2011). Microsatellite markers: an overview of the recent progress in plants. Euphytica 177(3):309-334.

Kandpal RP, Kandpal G, Weissman SM (1994). Construction of libraries enriched for sequence repeats and jumping clones, and hybridization selection for region-specific markers. Proceedings of the National Academy of Sciences 91(1):88-92.

Karagyozov L, Kalcheva ID, Chapman VM (1993). Construction of random small-insert genomic libraries highly enriched for simple sequence repeats. Nucleic Acids Research 21(16):3911-3912.

Karlin EF, Andrus RE, Boles SB, Shaw AJ (2011a). One haploid parent contributes $100 \%$ of the gene pool for a widespread species in northwest North America. Molecular ecology 20(4):753-767.

Karlin EF, Boles SB, Ricca M, Temsch EM, GreilhuberJ, Shaw AJ (2009). Three-genome mosses: complex double allopolyploid origins for triploid gametophytes in Sphagnum. Molecular Ecology 18(7):14391454.

Karlin EF, Boles SB, Seppelt RD, Terracciano S, Shaw AJ (2011b). The peat moss Sphagnum cuspidatum in Australia: microsatellites provide a global perspective. Systematic Botany 36(1):22-32.

Karlin EF, Melissa MG, Lake RA, Boles SB, Shaw AJ (2010). 
44

Microsatellite analysis of Sphagnum centrale, $S$. henryense, and $S$. palustre (Sphagnaceae). The Bryologist 113(1):90-98.

Kashi Y, King DG (2006). Simple sequence repeats as advantageous mutators in evolution. Trends in Genetics 22(5):253-259.

Kophimai Y, Peintinger M, Werth S, Cornejo C, Scheidegger C, Bergamini A (2014). Ploidy level, genetic diversity, and differentiation in two closely related mosses, Scorpidium cossonii and $S$. revolvens (Calliergonaceae). Journal of Bryology 36(1):33-43.

Korpelainen H, Allen NS (1999). Genetic variation in three species of epiphytic Octoblepharum (Leucobryaceae). Nova Hedwigia 68(3):281-290.

Kugita M, Kaneko A, Yamamoto Y, Takeya Y, Matsumoto T, Yoshinaga $\mathrm{K}$ (2003). The complete nucleotide sequence of the hornwort (Anthoceros formosae) chloroplast genome: insight into the earliest land plants. Nucleic Acids Research 31(2):716-721.

Kumar P, Gupta VK, Mishra AK, Modi DR, Pandey BK (2009). Potential of molecular markers in plant biotechnology. Plant Omics Journal 2(4):144-162.

Leonardia AA, Tan BC, Kumar PP (2012). Population genetics structure of the tropical moss Acanthorrhynchium papillatum as measured with microsatellite markers. Plant biology 15(2):384-94.

Levinson G, Gutman GA (1987). Slipped-strand mispairing: a major mechanism for DNA sequence evolution. Molecular Biology and Evolution 4(3):203-221.

Li L, Wang B, Liu Y, Qiu YL (2009). The complete mitochondrial genome sequence of the hornwort Megaceros aenigmaticus shows a mixed mode of conservative yet dynamic evolution in early land plant mitochondrial genomes. Journal of Molecular Evolution 68(6):66578.

Li YC, Korol AB, Fahima T, Beiles A, Nevo E (2002). Microsatellites: genomic distribution, putative functions, and mutational mechanisms: a review. Molecular Ecology 11(12):2453-2465.

Litt M, Lutty JA (1989). A hypervariable microsatellite revealed by in vitro amplification of dinucleotide repeat within the cardiac muscle actin gene. American Journal of Human Genetics 44(3):391-401.

Liu BH (1997). Statistical Genomics: Linkage, Mapping and QTL Analysis. CRC Press, Boca Raton, London.

Liu Y, Ge XJ, Sun QB, Cao T (2010). Development of microsatellite markers for the moss Ptychomitrium gardneri (Ptychomitriaceae). American Journal of Botany 97(3):14-16.

Liu Y, Xue JU, Wang B, Li L, Qiu YL (2011). The mitochondrial genomes of the early land plants Treubia lacunosa and Anomodon rugelii: Dynamic and conservative evolution. PLoS One 6(10):1-11.

Magain N, Forrest LL, Serusiaux E, Goffinet B (2010). Microsatellite primers in the Peltigera dolichorhiza complex (lichenized ascomycete, Peltigerales). American Journal of Botany 97(10):102-104.

McdonaldDB, Potts WK (1997). DNA microsatellites as genetic markers for several scales. In: Mindell DP (Ed). Avian molecular evolution and systematic. Academic Press, San Diego pp 29-49.

Merget B, Wolf M (2010). A molecular phylogeny of Hypnales (Bryophyta) inferred from ITS2 sequence-structure data. BioMed Central Research Notes 3(1):320-327.

Mikulaskova E, Hajek M, Veleba A, Johnson MJ, Hajek T, Shaw JA (2015). Local adaptations in bryophytes revisited: the genetic structure of the calcium-tolerant peatmoss Sphagnum warnstorfii along geographic and $\mathrm{pH}$ gradients. Ecology and Evolution 5(1):229-242.

Morgante M, Hanafey M, Powell W (2002). Microsatellites are preferentially associated with nonrepetitive DNA in plant genomes. Nature Genetics 30:194-200.

Murray V, Monchawin C, England PR (1993). The determination of the sequences present in the shadow bands of a dinucleotide repeat PCR Nucleic Acids Research 21(10):2395-2398.

Oda K, Yamato K, Ohta E, Nakamura Y, Takemura M, Nozato N, Akashi K, Kanegae T, Ogura Y, Kohchi T, Ohyama K (1992). Gene organization deduced from the complete sequence of liverwort Marchantia polymorpha mitochondrial DNA - A primitive form of plant mitochondrial genome. Journal of Molecular Biology 223(1):17.

Ohyama K, Fukuzawa H, Kohchi T, Shirai H, Sano T, Umesono K, Shiki Y, Takeuchi M, Chang Z, Aota S, Inokuchi H, Ozeki H (1986). Chloroplast gene organization deduced from complete sequence of liverwort Marchantia polymorpha chloroplast DNA. Nature 322(6079):572-574.

Oliver MJ, Murdock AG, Mishler BD, Kuehl JV, Boore JL Mandoli DF, Everett KD, Wolf PG, Duffy AM, Karol K (2010). Chloroplast genome sequence of the moss Tortula ruralis: gene content, polymorphism, and structural arrangement relative to other green plant chloroplast genomes. BioMed Central Genomics 11(1):143.

Olsson S, Buchbender V, Enroth J, Hedenas L, Huttunen S, Quandt D (2009). Phylogenetic analyses reveal high levels of polyphyly among pleurocarpous lineages as well as novel clades. The Bryologist 112(3):447-466.

Ostrander EA, Jong PM, Rine J, Duyk G (1992). Construction of smallinsert genomic DNA libraries highly enriched for microsatellite repeat sequences. Proceedings of the National Academy of Sciences 89(8):3419-3423.

Paasch AE, Mishler BD, Nosratinia S, Stark LR, Fisher KM (2015). Decoupling of sexual reproduction and genetic diversity in female biased Mojave Desert moss Syntrichia caninervis (Pottiaceae). International Journal of Plant Science 176(8):751-761.

Paetkau D (1999). Microsatellites obtained using strand extension: An enrichment protocol. Biotechniques 26(4):690-697.

Paetkau D, Strobeck C (1995). The molecular-basis and evolutionary history of a microsatellite null allele in bears. Molecular Ecology 4(4):519-520.

Park YJ, Lee JK, Kim NS (2009). Simple Sequence Repeat Polymorphisms (SSRPs) for evaluation of molecular diversity and germplasm classification of minor crops. Molecules 14(11):45464569.

Patterson E, Boles SB, Shaw AJ (1998). Nuclear ribosomal DNA variation in Leucobryum glaucum and L. albidum (Leucobryaceae): A preliminary investigation. The Bryotogist 101(2):272-277.

Powell W, Machray GC, Provan J (1996). Polymorphism revealed by simple sequence repeats. Trends in Plant Science 1(7):215-222.

Provan J, Russell JR, Booth A, Powell W (1999a). Polymorphic chloroplast simple sequence repeat primers for systematic and population studies in the genus Hordeum. Molecular Ecology 8(3):505-511. 
Provan J, Soranzo N, Wilson NJ, Goldstein DB, Powell WA (1999b). Low mutation rate for chloroplast microsatellites. Genetics 153(2):943-947.

Provan J, Wilson PJ (2007). Development of microsatellites for the peat moss Sphagnum capillifolium using ISSR cloning. Molecular Ecology Notes 7(2):254-256.

Queller DC, Strassman JE, Hughes CR (1993). Microsatellites and Kinship. Trends in Ecology and Evolution 8(8):285-288.

Rajendrakumar P, Biswal AK, Balachandran SM, Srinivasarao K, Sundaram RM (2007). Simple sequence repeats in organellar genomes of rice: frequency and distribution in genic and intergenic regions. Bioinformatics 23(1):1-4.

Ramaiya M, Johnson M, Shaw B, Heinrichs J, Hentschel J, Von-Konrat M, Davison PG, Shaw AJ (2010). Morphologically cryptic biological species within the liverwort, Frullania asagrayana. American Journal of Botany 97(10):1707-1718.

Ricca M, Beecher FW, Boles SB, Temsch E, Greilhuber J, Karlin EF, Shaw AJ (2008). Cytotype variation and allopolyploidy in North American species of the Sphagnum subsecundum complex. American Journal of Botany 95(12):1606-1620.

Ricca M, Shaw AJ (2010). Allopolyploidy and homoploid hybridization in the Sphagnum subsecundum complex (Sphagnaceae: Bryophyta). Biological Journal of the Linnean society 99(1):135-151.

Ricca M, Szovenyi P, Temsch EM, Johnson MG, Shaw AJ (2011). Interploidal hybridization and mating patterns in the Sphagnum subsecundum complex. Molecular Ecology 20(15):3202-3218.

Saghai-Maroof MA, Soliman KM, Jorgensen RA, Allard RW (1984). Ribosomal DNA spacer-length polymorphism in barley: mendelian inheritance, chromosomal location, and population dynamics. Proceedings of National Academy of Sciences 81(24):8014-8018.

Samigullin TH, Valiejo-Roman KM, Troitsky AV, Bobrova VK, Filin VR Martin W, Antonov AS (1998). Sequences of rDNA internal transcribed spacers from the chloroplast DNA of 26 bryophytes: properties and phylogenetic utility. Federation of European Biochemical Societies Letters 422(1):47-51.

Sastad SM (2005). Patterns and mechanisms of polyploid speciation in bryophytes. In: Bakker T, Chatrou-Gravendeel B, Pelser P (Eds). Plant Species Level Systematics: New Perspectives on Pattern and Process, Gantner Verlag, Ruggell, Liechtenstein pp 317-333.

Sastad SM, Stenoien HK, Flatberg KI, Bakken S (2001). The narrow endemic Sphagnum troendelagicum is an allopolyploid derivative of the widespread $S$. balticum and $S$. tenellum. Systematic Botany 26(1):66-74.

SawickiJ, Kwasniewski M, Szczecinska M, Chwialkowska K, Milewicz M, Plášk V (2012). Isolation and characterization of Simple Sequence Repeats (SSR) Markers from the moss Genus Orthotrichum using a small throughput pyrosequencing machine. International Journal of Molecular Sciences 13(6):7586-7593.

Schlotterer C, Tautz D (1992). Slippage synthesis of simple sequence DNA. Nucleic Acids Research 20(2):211-215.

Selkoe KA, Toonen RJ (2006). Microsatellites for ecologists: a practical guide to using and evaluating microsatellite markers. Ecology Letters 9(5):615-629.

Shanker A (2013a). Identification of microsatellites in chloroplast genome of Anthoceros formosae. Archive for Bryology 191:1-4.
Shanker A (2013b). Mining of simple sequence repeats in chloroplast genome of a parasitic liverwort: Aneura mirabilis. Archive for Bryology 196:1-4.

Shanker A (2014a). Computationally mined microsatellites in chloroplast genome of Pellia endiviifolia. Archive for Bryology 199:1-5.

Shanker A (2014b). Computational mining of microsatellites in the chloroplast genome of Ptilidium pulcherrimum, a liverwort. International Journal of Environment: 3(3):50-58.

Shaw AJ (2009). Bryophyte species and speciation. In: Goffinet BG, Shaw AJ (Eds). Bryophyte Biology, 2nd ed, Cambridge University Press, New Yorkpp 445-485.

Shaw J, Beer SC (1999). Life history variation in gametophyte populations of the moss Ceratodon purpureus (Ditrichaceae). American Journal of Botany 86(4):512-21.

ShawAJ, CaoT, WangLS, Flatberg KI, FlatbergB, ShawA, ZhouP, Boles $S$, Terracciano $S$ (2008). Genetic variation in three Chinese peat mosses (Sphagnum) based on microsatellite markers, with primer information and analysis of ascertainment bias. The Bryologist 111(2):271-281.

Shinde D, Lai Y, Sun F, Arnheim N (2003). Taq DNA polymerase slippage mutation rates measured by PCR and quasi-likelihood analysis: $(\mathrm{CA} / \mathrm{GT}) \mathrm{n}$ and $(\mathrm{A} / \mathrm{T}) \mathrm{n}$ microsatellites. Nucleic Acids Research 31(3):974-980.

Skotnicki ML, Mackenzie AM, Clements MA, Selkirk PM (2005).DNA sequencing and genetic diversity of the 18S-26S nuclear ribosomal internal transcribed spacers (ITS) in nine Antarctic moss species. Antarctic Science 17(3):377-384.

Skotnicki ML, Ninham JA, Selkirk PM (1998a). Genetic diversity in the moss Bryurn argenteum in Australia, New Zealand and Antarctica. The Bryologist 101:412-421.

Slatkin HI (1985). Gene flow in natural populations. Annual Review of Ecology and Systematics 16:393-430.

Smulders MJM, Bredemeijer G, Rus-Kortekaas W, Arens P, Vosman B (1997). Use of short microsatellites from database sequences to generate polymorphisms among Lycopersicon esculentum cultivars and accessions of other Lycopersicon species. Theoretical and Applied Genetetics 94(2):264-272.

Sotiaux A, Enroth J, Olsson S, Quandt D, Vanderpoorten A (2009). When morphology and molecules tell us different stories: a caseinpoint with Leptodon corsicus, a new and unique endemic moss species from Corsica. Journal of Bryology 31(3):186-196.

Stenoien HK, Sastad SM (2001). Genetic variability in bryophytes: does mating system really matter? Journal of Bryology 23(4):313-318.

Stenoien HK, Shaw AJ, Stengrundet K, Flatberg KI (2011). The narrow endemic Norwegian peat moss Sphagnum troendelagicum originated before the last glacial maximum. Heredity 106(2):370-382.

Sugiura C, Kobayashi Y, Aoki S, Sugita C, Sugita M (2003). Complete chloroplast DNA sequence of the moss Physcomitrella patens: evidence for the loss and relocation of rpoA from the chloroplast to the nucleus. Nucleic Acids Research 31(18):53245331.

Szovenyi P, Hock ZS, Korpelainen H, Shaw AJ (2009a). Spatial pattern of nucleotide polymorphism indicates molecular adaptation in the bryophyte Sphagnum fimbriatum. Molecular Phylogenetics and Evolution 53(1):277-286. 
46

Szovenyi P, Ricca M, Shaw AJ (2009b). Multiple paternity and sporophytic inbreeding depression in a dioicous moss species. Heredity 103(5):394-403.

Szovenyi P, Sundberg S, Shaw AJ (2012). Long-distance dispersal and genetic structure of natural populations: an assessment of the inverse isolation hypothesis in peat mosses. Molecular ecology 21(22):54615472.

Szovenyi P, Terracciano S, Ricca M, Giordano S, Shaw AJ (2008). Recent divergence, intercontinental dispersal and shared polymorphism are shaping the genetic structure of amphi-Atlantic peatmoss populations. Molecular ecology 17(24):53645377.

Tautz D, Renz M (1984). Simple sequences are ubiquitous repetitive components of eukaryotic genomes. Nucleic Acids Research 12(10):4127-4138.

Tautz D, Trick M, Dover GA (1986). Cryptic simplicity in DNA is a major source of genetic variation. Nature 322:652-656.

Terasawa K, Odahara M, Kabeya Y, Kikugawa T, Sekine Y, Fujiwara M, Sato $N$ (2007). The mitochondrial genome of the moss Physcomitrella patens sheds new light on mitochondrial evolution in land plants. Molecular Biology and Evolution 24(3):699-709.

Thiel T, Michalek W, Varshney RK, Graner A (2003). Exploiting EST databases for the development and characterization of gene-derived SSR-markers in barley (Hordeum vulgare L.). Theoretical and Applied Genetics 106(3):411-422.

Toth G, Gaspari Z, Jurka J (2000). Microsatellites in different eukaryotic genomes: survey and analysis. Genome Research 10(7):967-981.

Vanderpoorten A, Goffinet B (2006). Mapping uncertainty and phylogenetic uncertainty in ancestral character state reconstruction: an example in the moss genus Brachytheciastrum. Systematic Biology 55:957-971.

Vanderpoorten A, Shaw AJ (2010). The application of molecular data to the phylogenetic delimitation of species in bryophytes: A note of caution. Phytotaxa 9(1):229-237.

Vander-Velde M, Bijlsma R (2002). Phylogeography of five Polytrichum species within Europe. Biological Journal of the Linnean Society 78(2):203-213.

Vander-Velde M, Bijlsma R (2004). Hybridization and asymmetric reproductive isolation between the closely related bryophyte taxa Polytrichum commune and P. uliginosum. Molecular Ecology 13(6):1447-1454.

Vander-Velde M, During HJ, Vande-Zande L, Bijlsma R (2001a). The reproductive biology of Polytrichum formosum: clonal structure and paternity revealed by microsatellites. Molecular ecology 10(10):24232434.

Vander-Velde M, Strate HJV, Zande LV, Bijlsma R (2000). Isolation and characterization of microsatellites in the moss species Polytrichum formosum. Molecular Ecology 9(10):1678-1680.

Vander-Velde M, Vande-Zande L, Bijlsma R (2001b). Genetic structure of Polytrichum formosum in relation to the breeding system as revealed by microsatellites. Journal of Evolutionary Biology 14(2):288-295.

Varshney RK, Graner A, Sorrells ME (2005). Genic microsatellite markers in plants: features and applications. Trends in Biotechnology 23(1):48-55.
Varshney RK, Hoisington DA, Tyagy AK (2006). Advances in cereal genomics and applications in crop breeding. Trends in Biotechnology 24(11):490-499.

Vekemans X, Hardy OJ (2004). New insights from fine-scale spatial genetic structure analysis in plant populations. Molecular Ecology 13(4):921-935.

Victoria FC, Maia D, Oliveira ACD (2011). In silico comparative analysis ofSSR markers in Plants. BioMed Central Plant Biology 11(1):1-15.

Wang B, Xue JY, Li L, Liu L, Qiu YL (2009b). The complete mitochondrial genome sequence of the liverwort Pleurozia purpurea reveals extremely conservative mitochondrial genome evolution in liverworts. Current Genetics 55(6):601-609.

Wang ML, Barkley NA, Jenkins TM (2009a). Microsatellite markers in plants and insects. Part I: Applications of Biotechnology. Genes, Genomes and Genomics 3:54-67.

Weising K, Nybom H, WolffK, Kahl G (2005). DNA fingerprinting in plants. Principles, methods and applications. CRC Press, Boca Raton.

Wickett NJ, Zhang Y, Hansen SK, Roper JM, Kuehl JV Plock SA, Wolf PG, DePamphilis CW, Boore JL, Goffinet B (2008). Functional gene losses occur with minimal size reduction in the plastid genome of the parasitic liverwort Aneura mirabilis. Molecular Biology and Evolution 25(2):393-401.

Wilson PJ, Provan J (2003). Effect of habitat fragmentation on levels and patterns of genetic diversity in natural populations of the peat moss Polytrichum commune. The Royal Society 270(1517):881-886.

Wolfe AD, Liston A (1998). RAPD Markers. In: Soltis DE, Soltis PS, Doyle JJ (Eds). Molecular systematics of plants 11: DNA sequencing. Boston pp 43-86.

Wolko L, Antkowiak W, Lenartowicz E, Bocianowski J (2010). Genetic diversity of European pear cultivars (Pymus communis L.) and wild pear (Pyrus pyraster (L.) Burgsd.) inferred from microsatellite markers analysis. Genetic Resources and Crop Evolution 57(6):801-806.

Wright $S$ (1943). Isolation by distance. Genetics 28(2):114-138.

Wyatt R, Odrzykoski IJ, Cronberg N (2005). High levels of genetic variation in the haploid leafy liverwort Porella platyphylla from the southeastern United States. Journal of Bryology 27(3):247-52.

Wyatt R, Odrzykoski IJ, Stoneburner A (1989). High levels of genetic variability in the haploid moss Plagiomnium ciliare. Evolution 43(5):1085-1096.

Xue JY, Liu Y, Li L, Wang B, Qiu YL (2010). The complete mitochondrial genome sequence of the hornwort Phaeoceros laevis: Retention of many ancient pseudogenes and conservative evolution of mitochondrial genomes in hornworts. Current Genetics 56(1):53-61.

Zane L, Bargelloni L, Patarnello T (2002). Strategies for microsatellite isolation: a review. Molecular Ecology 11(1):1-16.

Zhao XC, Zhu RL, Liu Y (2014). Simple sequence repeats in bryophyte mitochondrial genomes. Mitochondria DNA 27(1):191-197.

Zhivotovsky LA, Feldman MW (1995). Microsatellite variability and genetic distances. Proceedings of the National Academy of Sciences 92(25):11549-11552.

Zouhair R, Corradini P, Defontaine A, Hallet JN (2000). RAPD markers for genetic differentiation of species within Polytrichum (Polytrichaceae, Musci): A preliminary survey. Taxon 49(2):217229. 